\title{
Optimization of costs for innovations of industrial enterprises Western Ukraine in ensuring sustainable environmental development
}

\author{
Vasyl Hyk \\ Lviv Polytechnic National University, Lviv, 79012, Ukraine
}

\begin{abstract}
The structural transformations taking place in the world economy are due to the transition from the «industrial economy» to the «knowledge economy», which is characterized by the dominance of intellectual capital and innovation. It is determined that an important condition for sustainable economic development of the country and increasing competitiveness is the effective implementation of innovation. The purpose of the study is to determine the optimal cost structure for innovation and its impact on sales revenue. Within this framework, attention is focused on the use of elements of economic and mathematical modeling. The scientific novelty is to develop a model that will substantiate the relationship between the studied indicators of innovation costs, will allow to predict the amount of income from sales and ensure the achievement of its optimal value. It is established that the proposed multiple linear regression quite clearly describes the initial data and can be used for prediction. The practical significance of the obtained results lies in the applied orientation of the approaches, the use of which improves the management of innovation costs and increases the level of reliability of economic information of industrial enterprises of Ukraine and as a result will improve the environmental situation. The study will assess the impact of economic entities on the environment and preserve the natural resource potential in order to achieve sustainable economic development.
\end{abstract}

\section{Introduction}

In the context of globalization, changes in the trajectory of economic progress lead to the acceleration of innovative development, the transition to a strategy based on knowledge and intelligence.

For the estimation of innovative development of country for today important are the international rating such as, Global Innovation Index, Bloomberg Innovation Index, Global Competitiveness Index, Innovation Union Scoreboard.

According to the Global Innovation Index [1], in 2019 Ukraine took 47th place in the ranking among 129 countries, in 2018 - 43rd place among 126 countries, while in 2017 - 50th place among 127 countries, so during the last three years there is no steady progress. However, compared to previous periods, Ukraine has established itself in the top 50 innovative countries in the world, surpassing such post-Soviet countries as Moldova, Georgia, Kazakhstan, Azerbaijan, Belarus, Kyrgyzstan, Tajikistan. Despite this, Ukraine still lags behind innovation-oriented countries in the ranking. Ukraine traditionally demonstrates the highest indicators of innovation in the field of education, which accordingly affects the country's overall innovation index. According to the indicator «Total expenditures on R\&D, \% of GDP» in 2019, Ukraine ranked 67th in the ranking $(0,4 \%$ of GDP). The value of this indicator remains low compared to other countries, especially innovation-oriented, which negatively affects the innovative development of the country.

In the structure of the index of global competitiveness [2] an important place is occupied by the sub-index «Innovation», which reflects the innovation component of the country. According to this sub-index, in 2019 Ukraine ranked 60th out of 141 countries and lagged behind some post-Soviet countries, including Estonia (34th place), Lithuania (42nd place) and Latvia (54th place).

In general, Ukraine's position in most rankings that analyze the level of innovative development, its potential and technological capabilities are not satisfactory for this stage of development. That is why the tasks of approaches to the analysis of innovation activity become especially important.

\section{Literature Review}

The first studies of innovation as an economic phenomenon were conducted by J.A. Schumpeter (18831950) [3], who interpreted innovation as a change in order to introduce and use new types of consumer goods, new means of production and transport, markets and forms of industrial organization. Economic categories

Corresponding author: Vasyl.V.Hyk@lpnu.ua 
«innovation», «innovation process» J.A. Schumpeter combined with the theory of long-term cyclic oscillations - the theory of «long waves» M.D. Kondratiev (1892-1931). In the 80's of the last century, based on the theory of J.A. Schumpeter, the famous German scientist-economist G.O. Mensh [4] in the book «Technological stalemate: innovation overcomes depression» concludes about the high concentration of basic innovations that overcome the «technological stalemate» and mark the beginning of a new trend in the economy - improving its key performance. G.O. Mensh explains the unevenness of innovation activity by the peculiarities of the functioning of a market economy.

At the present stage of economic development, many domestic scientists have dealt with the problems of analyzing the costs of innovation. Thus, Lisovska L.S., Karyy O.I. [5] investigated the factors for joint innovation between enterprises and proposed to group them according to certain characteristics. According to the authors, the use of these features will contribute to a better understanding of the principles and mechanisms of innovative cooperation. Tsenov M.O. [6] proposed a model of economic growth based on the innovative development of the enterprise, which consists in calculating the main indicators of the model and conducting a comparative analysis of indicators with real indicators of economic activity. The team of authors S. Bondarenko, L. Verbivska, N. Dobrianska, G. Iefimova, V. Pavlova, O. Mamrotska [7] studied the issues of managing the costs of innovation to ensure economic security. Within the framework of this methodology the principle of optimal management is presented. In the context of economic security I. Maslak, N. Ye. Grishko, O.O. Hlazunova, K.O. Vorobiova [8] also worked out approaches to cost management of innovative activities of mining enterprises. Fedulova I.V. [9] considered certain types of costs for innovation and their impact on the volume of sold innovative products and considered conceptual approaches to establishing their optimal structure based on performance. Olefirenko O.M. [10] presented an economic and mathematical model for optimizing sales costs of innovative and active machinebuilding enterprise. However, without diminishing the significant contribution of researchers, some problematic issues of the methodology of analysis and optimization of innovation costs remain unresolved.

\section{Model and Data Analysis}

One of the most important aspects of enterprise development is the optimization of costs or achieving a level that will provide the required financial result under certain conditions. To do this, use the elements of economic and mathematical modeling.

The mathematical model of optimizing the cost of innovation assumes that all variables, parameters, constraints and the objective function of the model are quantifiable. If variables $\mathrm{X}=\left(x_{1}, x_{2}, \ldots, x_{n}\right)$ are manageable variables, and $\mathrm{C}=\left(c_{1}, c_{2}, \ldots, c_{k}\right)$ parameters that can not be controlled, and the condition of the system under study is determined by $m$ constraints, the mathematical model can be written: find a point $\mathrm{Y}=\left(y_{1}, y_{2}, \ldots, y_{n}\right)$, in which the extremum (minimum or maximum) of the objective function is reached $\mathrm{f}(\mathrm{X}, \mathrm{C})$ :

with restrictions:

$$
f(Y, C)=\operatorname{extrf}(X, C)
$$

$$
\varphi_{i}\left\{\begin{array}{l}
(X C) \leq(\geq,=) v_{i}, i=1, m, \\
x_{j} \geq 0, j=1, n .
\end{array}\right.
$$

where, $\varphi_{i}-$ is a system of problem constraints that describes the necessary conditions for reaching the extremum.

Dependencies (1), (2) are an optimization economicmathematical model, in the construction of which it should be remembered that it must adequately describe the real economic processes occurring in the system, and take into account only significant phenomena in the process. The system of constraints or task (2) describes the necessary conditions for reaching the extremum. Schematically, the stages of the process of building a model for optimizing the cost of innovation are shown in Fig. 1.

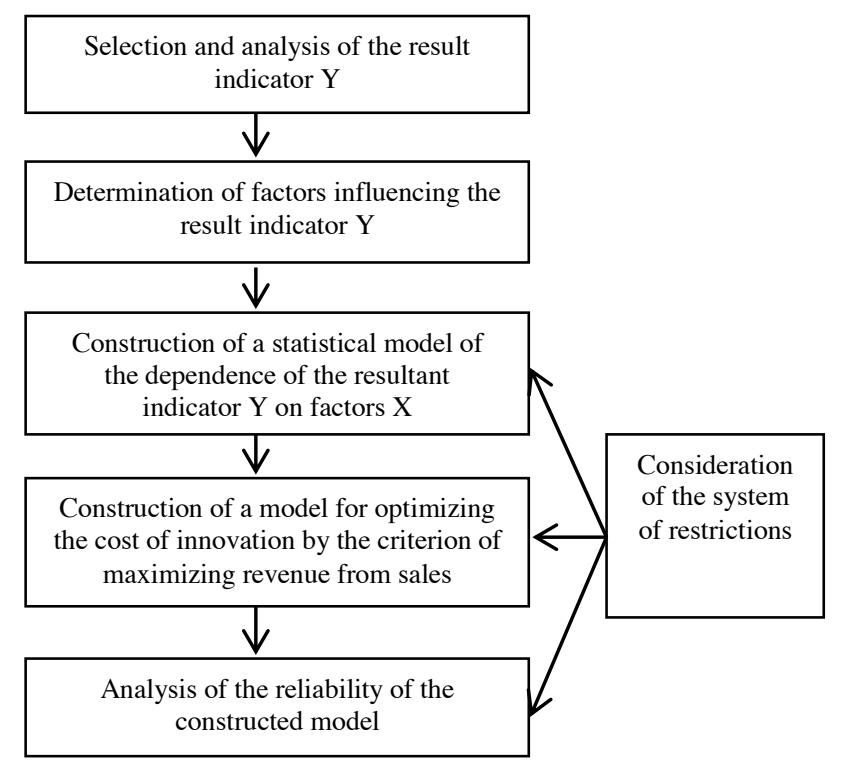

Fig. 1. Stages of building a model for optimizing the cost of innovation

Source: Developed by the author

The study will be conducted using the method of multiple linear regression to build a model of the relationship between the volume (income) from sales and cost elements for innovation of domestic industrial enterprises.

Optimization of innovation costs for the company is to achieve such volumes with given constraints, under which the income from sales will be maximum.

When forming the system of constraints of the model, it was important that the growth rate of sales 
revenue should exceed the growth rate of innovation costs. Thus, the system of conditions of the problem has the form:

$$
\left\{\begin{array}{l}
\frac{x_{1}}{x_{1}^{0}} \leq \frac{Q_{p}}{Q_{p}^{0}} \\
\frac{x_{2}}{x_{2}^{0}} \leq \frac{Q_{p}}{Q_{p}^{0}} \\
\cdots \\
\frac{x_{n}}{x_{n}^{0}} \leq \frac{Q_{p}}{Q_{p}^{0}} \\
x_{j} \geq 0, j=1, n
\end{array}\right.
$$

where $x_{1}^{0}, x_{2}^{0}, \quad x_{n}^{0}-$ indicators of expenses for innovations of the enterprise in the previous period; $Q_{p}$, $Q_{p}^{0}$ - income (amount) of sales in the current and base periods, respectively, UAH

As a factor of the cost of innovation, we propose to use the types of costs in the accounts [11]. In this case, the model of optimization of innovation costs by the criterion of income maximization will look like:

$\mathrm{Q}(\mathrm{x})=\mathrm{a}^{0}+\mathrm{a}_{1} \mathrm{x}_{1}+\mathrm{a}_{2} \mathrm{x}_{2}+\mathrm{a}_{3} \mathrm{x}_{3}+\mathrm{a}_{4} \mathrm{x}_{4}+\mathrm{a}_{5} \mathrm{x}_{5} \rightarrow \max$ where, $x_{1}-$ costs of innovations in the acquisition (creation) of new or improvement (modernization, reconstruction) of existing technologies, equipment, machinery, etc., thousand UAH;

$x_{2}$ - costs of innovations in the acquisition (creation) and implementation of copyright, intellectual property (inventions, utility models, industrial designs, etc.), thousand UAH.;

$x_{3}$ - costs of innovation as part of the costs of preparation and development of new products and production, thousand UAH.;

$x_{4}$ - costs of innovation as part of overhead costs, thousand UAH.;

$x_{5}$ - costs of innovation as part of other operating costs, thousand UAH.;

$Q(x)$ - income from sales of products, thousand UAH.

\section{Results and Discussion}

Using the initial data (Table 1) obtained from statistical collections; we determine the parameters of the model.

We make sure that the system of constraints of the model is calculated by calculating the growth rate (Table 2)

Table 1. Initial data for calculations of optimization of expenses for innovations on criterion of maximization of the income of the industrial enterprises Western Ukraine in 2018

\begin{tabular}{|c|c|c|c|c|c|c|}
\hline Name of the area & $\begin{array}{c}\text { Revenue from } \\
\text { sales of } \\
\text { industrial } \\
\text { products (goods, } \\
\text { services) UAH } \\
\text { billion. }(Q(x)\end{array}$ & $\begin{array}{c}\text { Expenses for } \\
\text { acquisition of } \\
\text { fixed assets, } \\
\text { thousand UAH } \\
\left(x_{1}\right)\end{array}$ & $\begin{array}{c}\text { Expenses for } \\
\text { acquisition of } \\
\text { intangible } \\
\text { assets, } \\
\text { thousand UAH } \\
\left(x_{2}\right)\end{array}$ & $\begin{array}{c}\text { Costs for } \\
\text { preparation and } \\
\text { development of } \\
\text { new types of } \\
\text { products, thousand } \\
\text { UAH }\left(x_{3}\right)\end{array}$ & $\begin{array}{c}\text { Costs as } \\
\text { part of } \\
\text { overhead } \\
\text { costs, } \\
\text { thousand } \\
\text { UAH }\left(x_{4}\right)\end{array}$ & $\begin{array}{c}\text { Research and } \\
\text { development } \\
\text { costs, thousand } \\
\text { UAH, }\left(x_{5}\right)\end{array}$ \\
\hline Lviv region & 110,50 & 178436,98 & 24332,32 & 107072,60 & 42829,04 & 64243,56 \\
\hline Volyn region & 33,40 & 54548,15 & 2870,96 & 15389,39 & 839,42 & 11751,89 \\
\hline $\begin{array}{c}\text { Transcarpathian } \\
\text { region }\end{array}$ & 25,80 & 19339,32 & 394,68 & 330,54 & 33,05 & 108,61 \\
\hline $\begin{array}{c}\text { Ivano-Frankivsk } \\
\text { region }\end{array}$ & 75,10 & 130088,55 & 11312,05 & 3079,63 & 233,31 & 1353,17 \\
\hline Ternopil region & 24,80 & 121389,29 & 6388,91 & 5040,15 & 1374,59 & 2749,17 \\
\hline Rivne region & 40,30 & 2011,88 & 62,22 & 2065,20 & 327,81 & 885,09 \\
\hline Chernivtsi region & 15,90 & 17253,77 & 1500,33 & 27078,44 & 351,67 & 7736,70 \\
\hline
\end{tabular}

Source: Compiled by authors based on [12 - 15].

Table 2. The value of growth rates of sales revenue and innovation costs of industrial enterprises of Western Ukraine in 2017-2018

\begin{tabular}{|l|c|c|c|c|c|c|}
\hline \multicolumn{1}{|c|}{ Name of the area } & $\frac{Q_{p}}{Q_{p}^{0}}$ & $\frac{x_{1}}{x_{1}^{0}}$ & $\frac{x_{2}}{x_{2}^{0}}$ & $\frac{x_{3}}{x_{3}^{0}}$ & $\frac{x_{4}}{x_{4}^{0}}$ & $\frac{x_{5}}{x_{5}^{0}}$ \\
\hline Lviv region & 1,349 & 0,955 & 1,173 & 0,961 & 1,244 & 1,133 \\
\hline Volyn region & 1,232 & 0,378 & 0,187 & 1,166 & 1,187 & 1,216 \\
\hline $\begin{array}{l}\text { Transcarpathian } \\
\text { region }\end{array}$ & 1,240 & 0,832 & 0,266 & 0,244 & 0,171 & 0,281 \\
\hline $\begin{array}{l}\text { Ivano-Frankivsk } \\
\text { region }\end{array}$ & 1,588 & 1,084 & 1,084 & 1,349 & 0,557 & 1,226 \\
\hline Ternopil region & 1,272 & 1,272 & 1,048 & 1,045 & 1,201 & 1,245 \\
\hline Rivne region & 1,172 & 0,366 & 0,272 & 1,173 & 1,136 & 1,057 \\
\hline Chernivtsi region & 1,529 & 0,795 & 0,918 & 1,372 & 0,264 & 1,382 \\
\hline
\end{tabular}

Source: Calculated by authors based on [12 - 15]. 
As can be seen from table. 3 the growth rate of sales revenue exceeds the growth rate of innovation costs for all parameter values $x\left(\frac{x_{n}}{x_{n}^{0}} \leq \frac{Q_{p}}{Q_{p}^{0}}\right)$, that is, it can be argued that the requirements of the system of restrictions are met.

To establish and determine the factors of influence, we will build a correlation matrix based on data for 2018 .

$R_{Q(x)}=\left(\begin{array}{llllll}1,000 & 0,914 & 0,602 & 0,679 & 0,644 & 0,775 \\ 0,914 & 1,000 & 0,839 & 0,893 & 0,864 & 0,923 \\ 0,602 & 0,839 & 1,000 & 0,969 & 0,989 & 0.737 \\ 0,679 & 0,893 & 0,969 & 1,000 & 0,985 & 0,823 \\ 0,644 & 0,864 & 0,989 & 0,985 & 1,000 & 0,781 \\ 0,775 & 0,923 & 0,737 & 0,823 & 0,781 & 1,000\end{array}\right)$

As a result of the correlation analysis between the factors of influence and the resulting value, it was found that they are adequate and with a high level of confidence describe the dependence of income from sales on the introduction of costs for innovation.

To build an econometric model, we determine the main coefficients of multifactor regression (Table 3 ).

The equation of the dependence of income from sales of products from these factors $x_{1}-x_{5}$ will look like:

$$
F(x)=39,2338-0,0007 x_{1}+0,0115 x_{2}-0,0017 x_{3}-0,0011 x_{4}
$$$$
+0,0022 x_{5}
$$

Let's construct the schedule of initial and result data, proceeding from the found equation of dependence (fig. 2).

Table 3. The results of calculating the coefficients of multifactor regression

\begin{tabular}{|l|c|c|c|c|c|}
\hline 0,002212131 & $-0,001086991$ & $-0,001663511$ & 0,011451209 & $-0,000699167$ & 39,23377612 \\
\hline 0,000983528 & 0,001016108 & 0,000439386 & 0,001690577 & 0,000135797 & 4,565111176 \\
\hline 0,995559236 & 5,55936605 & & & & \\
\hline 44,83729433 & 1 & & & & \\
\hline 6928,830592 & 30,90655088 & & & & \\
\hline
\end{tabular}

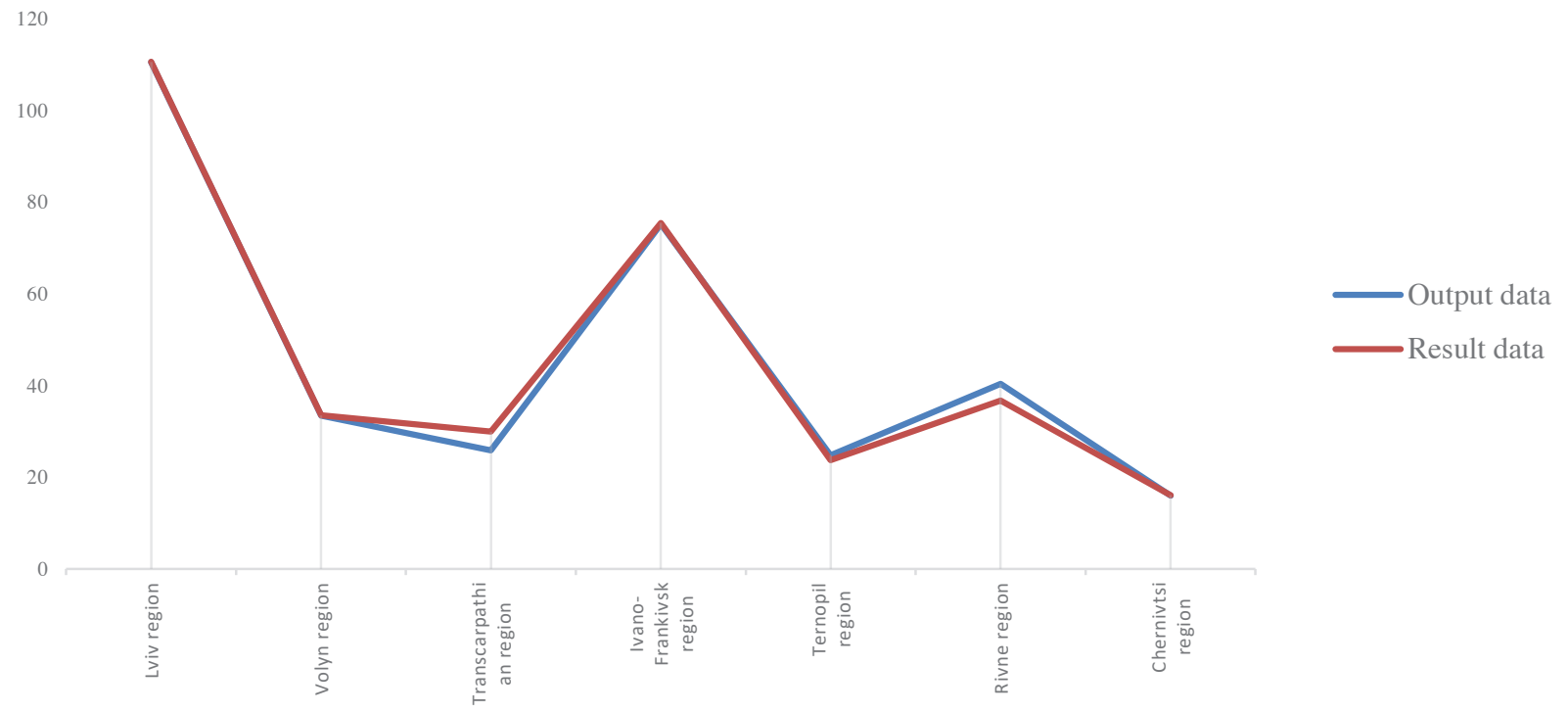

Fig. 2. Schedule of initial and result data of income from sales of products

As can be seen from Fig. 3 initial values of income from sales of products very well describe the results. Thus, we can conclude that the constructed multiple linear regression quite clearly describes the original data and it can be used to predict $F(x)$.

The coefficient of determination is 0,995 (see table. 4), which indicates a close relationship between the resultant and factor traits (variation of the resultant trait by $99,5 \%$ due to certain factors and only $0.05 \%$ - other factors that are not taken into account To determine the adequacy of the model, we find the value of the Fcriterion $F_{R}=44,8372$. Tabular value $F_{t a b}$ $(0,05 ; 7 ; 5)=4,3026$. Because $F_{R}>F_{t a b}(44,8372>4,3026)$, then the coefficient of determination is statistically significant.

\section{Conclusion}

One of the ways to reach a compromise between economic development and the ecological state of the environment is the implementation of the concept of sustainable development, which provides for further economic development taking into account the need to preserve the environment. The scale and nature of nature management have led to the fact that at the present stage a critical element in the system of economic relations are innovation costs, and opportunities for sustainable 
development largely depend on the efficiency of its use and reproduction. That is why the study of environmental and economic issues in Ukraine is extremely relevant.

Thus, the use of economic-mathematical model in planning the costs of innovation allows you to describe the relationships between the initial variables of the model, assess the impact of costs on performance, find the best solution for the value of these costs, and contributes to effective management.

In the course of the research the regularities of the influence of the level of total expenses on innovation activity on the indicators of financial results of industrial enterprises activity were revealed and the interdependence of these indicators was explained with the help of the formed formulas. The obtained results allow to evaluate the indicators of innovative development of industrial enterprises of Western Ukraine. Further application of the model allows to make the following analysis of innovation processes and forecasts of enterprise development depending on the direction of investments in innovation.

\section{References}

1. The Global innovation index 2019. 11th edition. Cornell University, INSEAD, (WIPO). Switzerland, Geneva: WIPO, 2019. _ _https://www.wipo.int /edocs/pubdocs/en/wipo_pub_gii_2019.pdf.

2. The Global Competitiveness Report 2019. Switzerland, Geneva: World Economic Forum, 2019.

http://www3.weforum.org/docs/WEF_TheGlobalCo mpetitivenessReport2019.pdf.

3. J.A. Schumpeter. The theory of economic development: an inquiry into profits, capital, credit, interest, and the business cycle (1912-1934). (Transaction Publishers, 1982).

4. G. Mensch. Title stalemate in technology: innovations overcome the depression (Cambridge, 1979).

5. L.S. Lisovska, O.I. Karyy. Econ., Entrepr., Manag. 7(1), (2020).

6. M.O. Tsenov. Bul. of Zapor. Nat. Univ.: Econ. Sc. 1(5), 118 (2010).

7. S. Bondarenko, L. Verbivska, N. Dobrianska, G. Iefimova, V. Pavlova, O. Mamrotska. Inter. Jour. of Rec. Techn. and Engin. 8(3), 5609 (2019).

8. O.I. Maslak, N.Ye. Grishko, O.O. Hlazunova, K.O. Vorobiova. Scient. Bull. of the Nat. Min. Univ. № 5, 137 (2017).

9. I.V. Fedulova. Probl. of impr. the effic. of infrastr. 34, 182 (2012).

10. O.M. Olefirenko. Intellig. XXI. 3, 64 (2017).

11. V.O. Ozeran, V.V. Hyk. Account. and Audit. 12, 21 (2013).

12. Statistical Atlas of the Regions of Ukraine of the State Statistics Service of Ukraine http://database.ukrcensus.gov.ua/dw_regions/pdf $/ \%$ D0\%90\%D1\%82\%D0\%BB\%D0\%B0\%D1\%81.pdf.

13. The volume of sold industrial products by region in 2017

http://www.ukrstat.gov.ua/operativ/operativ2013/pr/ orp_reg/orp_reg_u/orp_reg1217_u.htm.

14. Statistical collection «Scientific and innovative activities of Ukraine in 2018» http://www.ukrstat.gov.ua/druk/publicat/kat_u/2019/ zb/09/zb_nauka_2018.pdf.

15. Statistical collection «Scientific and innovative activities of Ukraine in 2017» http://www.ukrstat.gov.ua/druk/publicat/kat_u/2018/ zb/09/zb_nauka_2017.pdf. 